\title{
A study to determine socio demographic corelates of reproductive tract infection amongst women of reproductive age group
}

\author{
Anmol K. Gupta, Anita Thakur, Tripti Chauhan, Nidhi Chauhan*
}

Department of Community Medicine, Indira Gandhi Medical College, Shimla, Himachal Pradesh, India

Received: 15 June 2020

Accepted: 08 July 2020

*Correspondence:

Dr. Nidhi Chauhan,

E-mail: ariessimla@gmail.com

Copyright: (C) the author(s), publisher and licensee Medip Academy. This is an open-access article distributed under the terms of the Creative Commons Attribution Non-Commercial License, which permits unrestricted non-commercial use, distribution, and reproduction in any medium, provided the original work is properly cited.

\begin{abstract}
Background: Reproductive tract infection (RTI) is a public health problem, especially in developing country like India. The associated odium with this reproductive morbidity is often a stumbling block in seeking health care. The aim was to study the prevalence of RTI symptoms and its socio-demographic corelates.

Methods: A cross-sectional study was undertaken in the rural field practice area of department of community medicine, Indira Gandhi Medical College, Shimla, Himachal Pradesh, India, from July 2018 to September 2018. Total sample size calculated was 410. Random sampling was used to select eligible couple to whom a predesigned, pretested, semi-structured and anonymous interview schedule was administered after taking consent.

Results: The prevalence of self-reported reproductive tract infections was found to be $41.2 \%$. The prevalence was more in lower socio-economic classes, and it was statistically significant. Other socio-demographic corelates (age, education, occupation) did not showed any significant association.

Conclusions: The reproductive tract infections prevalence is found to be considerably high in the women of reproductive age group. The frequency was higher among multigravida women and those using cloth during menstrual periods. RTIs are usually spurned by women and even the health care providers, so there is a need to give due consideration to this aspect of reproductive health.
\end{abstract}

Keywords: Cross-sectional, Prevalence, Reproductive tract infections, Women of reproductive age group

\section{INTRODUCTION}

Sexually transmitted infections (STI) constitute a significant health burden and its very well known for increasing the risk of HIV transmission. ${ }^{1}$

Reproductive tract infection (RTI) is common yet neglected global health problem, mainly among reproductive age group of women, living in South East Asian Region (SEAR) countries. The prevalence of RTI in India and countries like Bangladesh, Egypt, and Kenya is in the range of $52-90 \% .^{2}$

The prevalence of self-reported RTI symptoms among women in reproductive age group in India has been found to be $11-18 \%$ in nationally representative studies. ${ }^{3,4}$
According to the World Health Organization (WHO), each year around 499 million cases of curable STIs occur throughout the world in the age group of 15-49 years, of which $80 \%$ cases occur in developing countries and about 79 million cases occur in India annually. ${ }^{5}$

Reproductive tract infections (RTIs) are caused by organisms which are commensals in reproductive tract or introduced from the outside during sexual contact or medical procedures. Reproductive tract infections (RTIs) include three types of infection: 1) sexually transmitted diseases (STDs), such as chlamydia, gonorrhoea, chancroid, and human immunodeficiency virus (HIV); 2) endogenous infections, caused by overgrowth of organisms normally present in the genital tract of healthy women, such as bacterial vaginosis or vulvovaginal 
candidiasis; and 3) iatrogenic infections, that are associated with improperly performed medical procedures like unsafe abortion or poor delivery practices. $^{6}$

The consequences of STIs/RTIs can be severe and life threatening. They include pelvic inflammatory disease (PID), infertility (in women and men), ectopic pregnancy, and adverse pregnancy outcomes including miscarriage, stillbirth, preterm birth, and congenital infection. STIs/RTIs are found to increase the risk of HIV transmission also. ${ }^{7}$ With early detection and treatment, RTIs and its complications can be prevented and severity of long-term sequel can be further minimized. Despite these facts, RTIs still remain undiagnosed and untreated.

Cultural barriers, poor understanding of symptoms, lack of privacy, lack of a female doctor at the health facility, the cost of treatment, social stigma, and fear of internal check-up delay seeking treatment. ${ }^{8-12}$ All such barriers pose a challenge for the effective implementation of programs that are aimed at the prevention and control. ${ }^{13}$

\section{METHODS}

A population based descriptive cross-sectional study. Women of reproductive age (15-49 years) in rural field practice area of Department of Community Medicine, IGMC, Shimla, Himachal Pradesh, India. The duration of this study was 3 months July 2018 to September 2018. With an area population of 81,000 the eligible couples came out to be 12,150 to 14,580 . Considering a population of 13,000 with prevalence of reproductive ill health as $50 \%$, with $5 \%$ margin of error and $95 \%$ confidence limits, a sample of 373 is calculated. Further, taking a non-response rate of $10 \%$, final sample comes out to be 410 . All the participants during the study duration who fulfilled the inclusion criteria were recruited in the study.

\section{Inclusion criteria}

- $\quad$ Resident of the area (residing for $>6$ months)

- $\quad$ Ever married females (15-49 years)

- Consented to participate in study.

\section{Exclusion criteria}

- Chronic serious/debilitating patient

- Any psychiatric illness.

\section{Study tool}

Interview schedule used was predesigned, pretested, semi-structured and anonymous.

\section{Sampling strategy}

The representative sample was selected from the eligible couple register, using the random numbers that were generated using the Microsoft excel. The selected subjects were then approached for data collection. In case the selected participant was not available, then the next participant in the eligible couple register was selected for the interview.

At the time of study enrolment, the anonymity of the participants was maintained and after obtaining the informed consent only, authors conducted a face-to-face interview of eligible candidates and filled the interview schedule.

\section{Exposure variables}

Included socio-demographic variables like age, type of family, education of participants and their spouse, occupation, socio-economic status and parity.

\section{Outcome variables}

Reproductive tract infections like vaginal discharge, itching, lower abdominal pain, genital ulcers and redness, burning pain during micturition.

\section{RESULTS}

Of 410 ever married women studied, 94 (22.3\%) were pregnant at the time of survey. Mean age of participants was $28.9 \pm 5.9$ years ranging from $19-48$ years. Majority of the participants $(70.2 \%)$ were aged less than 30 years and $61.2 \%$ were home-maker (Table 1 ).

Table 1: Distribution of study participants according to socio-demographic characteristics $(\mathrm{N}=410)$.

\begin{tabular}{|c|c|}
\hline Socio demographic variables & $\mathbf{N}(\%)$ \\
\hline \multicolumn{2}{|l|}{ Type of family } \\
\hline Nuclear & $196(47.8 \%)$ \\
\hline Joint & $132(32.2 \%)$ \\
\hline Three generation & $82(20 \%)$ \\
\hline \multicolumn{2}{|l|}{ Religion } \\
\hline Hindu & $408(99.5 \%)$ \\
\hline Muslim & $2(0.5 \%)$ \\
\hline \multicolumn{2}{|l|}{ Educational status } \\
\hline Illiterate & $12(2.9 \%)$ \\
\hline Primary School & $34(8.3 \%)$ \\
\hline Middle School & $46(11.2 \%)$ \\
\hline High School & $139(33.9 \%)$ \\
\hline Secondary School & $96(23.4 \%)$ \\
\hline Graduate & $45(10.9 \%)$ \\
\hline Post-graduate & $38(9.3 \%)$ \\
\hline \multicolumn{2}{|l|}{ Occupation } \\
\hline Govt. Employee & $27(6.6 \%)$ \\
\hline Self-employed & $19(4.6 \%)$ \\
\hline Agricultural worker & $63(15.4 \%)$ \\
\hline Housewife & $251(61.2 \%)$ \\
\hline Private Company & $50(12.2 \%)$ \\
\hline
\end{tabular}


Table 2: Distribution of reproductive tract infections among study participants $(\mathrm{N}=410)$.

\begin{tabular}{|llll|}
\hline Characteristics & Pregnant (94) N (\%) & Non-pregnant (316) N (\%) & Total N (\%) \\
\hline Lower abdominal pain & $13(13.8 \%)$ & $44(13.9 \%)$ & $57(13.9 \%)$ \\
\hline Foul smelling discharge & $17(18.1 \%)$ & $44(13.9 \%)$ & $123(30 \%)$ \\
\hline Burning pain during micturition & $9(9.6 \%)$ & $16(5.06 \%)$ & $25(6.1 \%)$ \\
\hline Redness in genital area & $11(11.7 \%)$ & $17(5.4 \%)$ & $28(6.8 \%)$ \\
\hline Genital ulcers/sores & $1(1.1 \%)$ & $5(1.6 \%)$ & $6(1.5 \%)$ \\
\hline Genital itching & $30(31.9 \%)$ & $15(4.8 \%)$ & $45(10.9 \%)$ \\
\hline Something bulging out of vagina & $0(0.0 \%)$ & $2(0.6 \%)$ & $2(0.5 \%)$ \\
\hline Overall RTI prevalence & $48(51.1 \%)$ & $121(38.3 \%)$ & $169(41.2 \%)$ \\
\hline
\end{tabular}

Table 3: Association of socio-demographic variables and reproductive tract infections $(\mathrm{N}=316)$.

\begin{tabular}{|c|c|c|c|}
\hline \multirow{2}{*}{ Characteristics } & \multicolumn{2}{|c|}{ Reproductive tract infection } & \multirow{2}{*}{ p-value } \\
\hline & Present & Absent & \\
\hline \multicolumn{4}{|l|}{ Age group (years) } \\
\hline $15-25$ & $68(53.5 \%)$ & $59(46.5 \%)$ & \multirow{3}{*}{0.176} \\
\hline $26-35$ & $118(52 \%)$ & $109(48 \%)$ & \\
\hline $36-49$ & $22(39.3 \%)$ & $34(60.7 \%)$ & \\
\hline \multicolumn{4}{|l|}{ Education } \\
\hline Illiterate & $8(66.7 \%)$ & $4(33.3 \%)$ & \multirow{3}{*}{0.105} \\
\hline$\leq$ High school & $119(54.3 \%)$ & $100(45.7 \%)$ & \\
\hline$>$ High school & $81(45.3 \%)$ & $98(54.7 \%)$ & \\
\hline \multicolumn{4}{|l|}{ Occupation } \\
\hline Employed & $47(49.5 \%)$ & $48(50.5 \%)$ & \multirow{3}{*}{0.153} \\
\hline Agricultural worker & $39(61.9 \%)$ & $24(38.1 \%)$ & \\
\hline Home-maker & $122(48.4 \%)$ & $130(51.6 \%)$ & \\
\hline \multicolumn{4}{|l|}{ Education of spouse } \\
\hline Illiterate & $1(20 \%)$ & $4(80 \%)$ & \multirow{3}{*}{$* 0.012$} \\
\hline$\leq$ High school & $115(57.8 \%)$ & $84(42.2 \%)$ & \\
\hline >High school & $92(44.7 \%)$ & $114(55.3 \%)$ & \\
\hline \multicolumn{4}{|c|}{ Socio-economic status } \\
\hline Upper class & $57(34.5 \%)$ & $108(65.5 \%)$ & \multirow{5}{*}{$* 0.025$} \\
\hline Upper middle class & $109(57.4 \%)$ & $81(42.6 \%)$ & \\
\hline Middle class & $24(68.6 \%)$ & $11(31.4 \%)$ & \\
\hline Lower middle class & $10(90.9 \%)$ & $1(9.1 \%)$ & \\
\hline Lower class & $8(88.9 \%)$ & $1(11.1 \%)$ & \\
\hline
\end{tabular}

p value $<0.05$ significant.

Only $27.1 \%$ of the participants had heard about one or the other reproductive tract infection. The prevalence of selfreported reproductive tract infections (RTIs) among the women of reproductive age group was found to be $41.2 \%$. The prevalence of RTI was more among currently pregnant women $(51 \%)$, compared to females who were not pregnant at the time of study (38.3\%). The most common infection was found to be foul smelling discharge $(30 \%)$, followed by lower abdominal pain (14\%) genital itching (11\%) (Table 2).

Nearly half $(52 \%)$ of the participants sought treatment for reproductive tract infections from the hospital. The most common reason among those not seeking the treatment was the unavailability of female doctor $(2.9 \%)$, and $1.7 \%$ were hesitant as they were embarrassed or ashamed about the complaint. The prevalence of reproductive tract infections was more in lower socioeconomic classes, and it was statistically significant ( $p$ value 0.025 ). Other socio-demographic corelates (age, education, occupation) did not showed any significant association with the presence of reproductive tract infections. Though, the reproductive tract infections were found to decrease with the age and (chi-square=2.32 and $\mathrm{p}$ value 0.126 ) and schooling (chi-square $=4.44$ and $\mathrm{p}$ value 0.03 ), but it was not statistically significant (Table 3).

\section{DISCUSSION}

The study sought to identify the prevalence of selfreported RTI among women living in rural areas, the 
determinants of the infection, health care seeking behaviour for the same.

The prevalence of self-reported reproductive tract infections was found to be $41.2 \%$, with foul smelling vaginal discharge $(30 \%)$ being the most common reported infection followed by lower abdominal pain $(13.9 \%)$, itching around vagina $(10.9 \%)$, burning pain on micturition $(6 \%)$. Nearly half of the participants sought treatment from the health institutions.

Almost similar to this findings, the prevalence of RTI was reported in a study among married women of reproductive age in a village in Nepal. The most common symptoms experienced that were suggestive of RTI include low back pain, $32.6 \%$, followed by vaginal discharge, $26.7 \%$, low abdominal pain, $19.4 \%$, itching around vagina, $15.9 \%$, painful or burning urination, $10.5 \% .^{14}$

Another study done in an urban slum of North-East Delhi, on the prevalence of reproductive tract infections, concluded that $43.9 \%$ women currently had symptoms of RTIs. These findings were also congruous with this study results. $^{15}$

NFHS-4 survey found the prevalence of self-reported sexually transmitted infections or symptoms of an STI (a bad-smelling, abnormal discharge from the vagina, a genital sore, or a genital ulcer) to be $11 \% .{ }^{16}$

Half of all symptomatic women did not seek health care for RTI symptoms, primarily because women were not aware that the symptoms required treatment.

This study observation commenced that most rural Indian women did not seeked care for reproductive symptoms due to a lack of knowledge, unavailability of female doctor, followed by their hesitancy to talk about symptoms.

A Chennai based study on RTIs, found that the reason for symptomatic women not seeking any treatment was the perception that their symptoms were normal as well as lack of family support, financial constraints, lack of decision-making power and embarrassment. ${ }^{17}$ Another study in Tamil Nadu by Geeta Mani, found stigma and embarrassment, lack of privacy, lack of female doctors at health facilities and treatment cost to be the most common reasons for not seeking treatment. ${ }^{18}$

This study found that, nearly half of the reproductive tract infections were found in the age group of 26 to 35 years (52\%). Similar results were found in studies by Sharma S et al, Nandan et al and Rabiu KA et al. ${ }^{19-21}$ This can be explained by the facts that with increasing age women experienced longer married life, pregnancies, gynecological examinations, deliveries, use of invasive contraceptives; make women more vulnerable to RTIs. This explanation is further supported by the observation made in the present study that nearly half of the multigravida women had one or the other RTI. ${ }^{20-21}$

The present study found socio-economic status to be a potential determinant, which were associated with the RTIs. 90\% participants belonging to lower class reported reproductive tract infections and $71.4 \%$ RTI was found in participants using cloth.

Similar results were found in a study by Bhilwar et al, where the odds of having RTI were more in women belonging to the lower socio-economic status (OR 2.1, 95\% CI: 1.5-2.9). ${ }^{15}$ Women using cloth during menses, those having more than three pregnancies and those using an intrauterine contraceptive had higher odds of having RTIs.

The current study, found the prevalence of RTI was highest among agricultural workers. However, no significant association between RTI and occupation could be seen $(p=0.153)$. RTIs were more common in lower socioeconomic strata, and it was found to be significant ( $\mathrm{p}$ value $=0.02)$.

Comparable to this study were the findings of Gupta $U$ et al in Lucknow. $^{22}$ A similar result found in the study carried out by Parashar A et al in Shimla town in which majority of symptomatic women belong to lower middle class. $^{23}$

The present study showed that prevalence of RTI/STD was low among more educated females in comparison to less educated and illiterate women. This finding was similar to the findings of Gupta $U$ et al, Panda et al, Deokinandan et al, data from NFHS-4 survey, Ranjan et al, Pant et al, Rathore et al and Datey et al. ${ }^{22,25-29}$

The current study found that there was a significant association ( $p$ value $=0.012$ ) found with the women having symptoms of reproductive tract infections and their educational status of husbands, which was similar to the study by Thekdi KP et al. ${ }^{30}$ The prevalence of reproductive tract infections of women was found to be decreased, with the improvement in their husbands' educational status suggesting the important role of the education in preventing sexually transmitted diseases.

The present study found that the prevalence RTI was higher in those participants who had poor menstrual hygiene. The prevalence of RTI was significantly associated with menstrual hygiene $(p=0.019)$. This was found identical with the findings of Gupta $U$ et al, Rathore et al, Sinha and Mishra and Pant et al, which showed the higher prevalence of RTI among women with poor hygiene..$^{22,28,31}$

\section{CONCLUSION}

The reproductive tract infections prevalence is found to be considerably high in the women of reproductive age 
group. The frequency was higher among multigravida women and those using cloth during menstrual periods. RTIs are usually spurned by women and even the health care providers, so there is a need to give due consideration to this aspect of reproductive health. The knowledge about various maternal and child health programmes, safe abortion services and medical termination of pregnancy need to be contemplated. The awareness regarding the screening for cervical and breast cancer need to be reinforced, so that overall reproductive health of women is improved in context to the target set for universal health coverage.

\section{ACKNOWLEDGMENTS}

Authors would like to acknowledge colleague's and staff of rural training Health Centre Mashobra for their constant help.

Funding: No funding sources

Conflict of interest: None declared

Ethical approval: The study was approved by the Institutional Ethics Committee

\section{REFERENCES}

1. UNFPA, top level push to tackle priorities in sexual and reproductive health, United Nations Population Fund, New York, NY, USA, 2006. Available at: https://www.unfpa.org/press/top-level-push-tacklepriorities-sexual-and-reproductive-health. Accessed on $16^{\text {th }}$ June 2020.

2. UNFPA, common reproductive tract infections, No. 9, 1999. Available at: https://www.unfpa.org/sites/default/files/pubpdf/sti_breaking.pdf. Accessed on 17 $7^{\text {th }}$ June 2020.

3. International institute for population sciences (IIPS), District level household and facility survey (DLHS3), 2007-08, IIPS, Mumbai, India, 2010. Available at: http://rchiips.org/pdf/INDIA_REPORT_DLHS3.pdf. Accessed on $17^{\text {th }}$ June 2020.

4. IIPS and Macro International, National Family Health Survey (NFHS-3), 2005-06: India, vol. 1, IIPS, Mumbai, India, 2007. Available at: http://rchiips.org/nfhs/NFHS-3\%20Data/VOL1/India_volume_I_corrected_17oct08.pdf. Accessed on $16^{\text {th }}$ June 2020 .

5. WHO Sexually transmitted infections (STIs) Available at: http://www.who.int/mediacentre/ factsheets/fs110/en/index.html. Accessed on $15^{\text {th }}$ September 2019.

6. Wasserheit JN, Holmes KK. Reproductive tract infections: challenges for international health policy, programs, and research. In: Germain A, Holmes KK, Piot P, Wasserheit JN, editors. Reproductive tract infections: global impact and priorities for women's reproductive health. New York: Plenum Press; 1992:7-33.

7. Integrating STI/RTI Care for Reproductive Health, Sexually Transmitted and Other Reproductive Tract
Infections: Reproductive Health and Research, World Health Organization; 2005.

8. Barua A, Kurz K. Reproductive health-seeking by married adolescent girls in Maharashtra, India. Reprod Health Matters. 2001;9(17):53-62.

9. Santow G. Social roles and physical health: the case of female disadvantage in poor countries. Soc Sci Med. 1995;40(2):147-61.

10. Bandopadhyay M, MacPherson S. Women and Health: Tradition and Culture in Rural India. Brookfield, VT: Ashgate Publishing; 1998.

11. World Bank. Improving Women's Health in India. Washington, DC: World Bank, 1996. Available at: http://documents.worldbank.org/curated/en/2860514 68771312911/Improving-womens-health-in-India. Accessed on $16^{\text {th }}$ June 2020.

12. Chaturvedi J. Screening of married women in the reproductive age group for reproductive tract infections in a village of Garhwal. South East Asian Studies Manual; 2000:134-138.

13. Population Council, New Delhi. Looking back, looking forward, a profile of sexual and reproductive health in India, 2004. Available at: http://www.searo. who.int/Link Files/Reporductive_Health_Profile_ RHP-India.pdf. Accessed on $20^{\text {th }}$ December 2019.

14. Kafle P, Bhattarai S. Prevalence and factors associated with reproductive tract infections in Gongolia village, Rupandehi district, Nepal. Hindawi Publishing Corporation, Advances in Public Health. 2016; Article ID 8063843.

15. Bhilwar M, Lal P, Sharma N, Bhalla P, Kumar A. Prevalence of reproductive tract infections and their determinants in married women residing in an urban slum of North-East Delhi, India. J Nat Sci Biol Med. 2015;6 (Suppl 1):S29-S34.

16. International Institute for Population Sciences (IIPS) and ICF. 2017. National Family Health Survey (NFHS-4), 2015-16: India. Mumbai: IIPS. Available at: http://rchiips.org/nfhs/NFHS-4Reports/India.pdf. Accessed on $17^{\text {th }}$ June 2020.

17. Anitha S, Dharmaraj D, Duttagupta KK, Abhinaya B, Lekha A. Arvind AK, et al. Reproductive tract infections among women of reproductive age group (15-49 years) - a Chennai based study. J Dent Med Sci. 2016;15(4):74-8.

18. Mani G. Prevalence of reproductive tract infections among rural married women in Tamil Nadu, India: A community-based study. J Pioneer Med Sci. 2014;4:18-24.

19. Sharma S, Gupta BP. The prevalence of reproductive tract infections and sexually transmitted diseases among married women in the reproductive age group in a rural area. Indian J Comm Med. 2009;34(1):624.

20. Nandan D, Misra SK, Sharma A, Jain M. Estimation of prevalence of RTIs/STDs among women of reproductive age group in Distt. Agra. Indian $\mathbf{J}$ Comm Med. 2002;27(3):110.

21. Rabiu KA, Adewunmi AA, Akinlusi FM, Akinola OI. Female reproductive tract infections: 
understandings and care seeking behaviour among women of reproductive age in Lagos, Nigeria. BMC Women's Health. 2010;10(1):8.

22. Gupta U, Sinha P, Inam L, Gupta S. Sociodemographic profile of reproductive tract infections and sexually transmitted diseases in reproductive aged women. Int $\mathbf{J}$ Reprod Contracept Obstet Gynecol. 2015;4:595-600.

23. Parashar A, Gupta BP, Bhardwaj AI, Sarin R. Prevalence of RTIs among women of reproductive age group in Shimla City. Indian J Comm Med. 2006;31(1):15-7.

24. Panda SC, Sarangi L, Bebartta D, Parida S, Panigarhi OP. Prevalence of RTI/STI among women of reproductive age in district Sundergarh (Orissa) Indmedica. Indian J Pract Doct. 2007;4(1):516.

25. Deoki N, Mishra SK, Sharma A, Jain M. Estimation of prevalence of RTI/STD among women of reproductive age group in district Agra. Indian $\mathbf{J}$ Community Med. 2002 Jul-Sep;27(3):110-3.

26. Ranjan R, Sharma AK, Mehta G. Evaluation of WHO diagnostic algorithm for reproductive tract infections among married women. Indian J Community Med. 2003;28(2):81-4.

27. Pant B, Singh JV, Bhatnagar M, Garg SK, Chopra H, Bajpai SK. Social correlates in reproductive tract infections among married women in rural area of Meerut. Indian J Community Med. 2008;33(1):52-3.

28. Rathore M, Vyas L, Bhardwaj AK. Prevalence of Reproductive Tract Infections amongst ever married women and sociocultural factors associated with it. J Indian Med Assoc. 2007;105:71-4.

29. Datey S, Bedi N, Gaur LN, Saxena NC, Saxena BN. Sexually transmitted infections (STIs) among antenatal women at five tertiary level hospitals in India. J Obstet Gynecol India. 2003;53(1):53-8.

30. Thekdi KP, Patel KG, Patel NK, Thekdi PI. A cross sectional study on the prevalence of reproductive tract infections amongst married women in the rural area of Surendranagar district. Int J Res Med Sci. 2014;2:215-21.

31. Sinha HH, Mishra MG. Socio demographic Profile and clinical evaluation of RTIs in rural women of Patna. J Obstet Gynecol India. 2001;51(6):124-6.

Cite this article as: Gupta AK, Thakur A, Chauhan T, Chauhan N. A study to determine socio demographic corelates of reproductive tract infection amongst women of reproductive age group. Int $\mathbf{J}$ Reprod Contracept Obstet Gynecol 2020;9:3463-8. 